\title{
Hordas de violadores. A instrumentalização da violência sexual em discursos anticomunistas alemães da Guerra Fria
}

"Hordes of Rapists". The Instrumentalization of Sexual Violence in German Anticommunist Discourses during the Cold War

Des hordes de violeurs. L'instrumentalisation de la violence sexuelle dans des discours anticommunistes allemands durant la Guerre Froide

Júlia Garraio

\section{OpenEdition}

\section{Journals}

Edição electrónica

URL: http://journals.openedition.org/rccs/4811

DOI: $10.4000 /$ rccs. 4811

ISSN: 2182-7435

\section{Editora}

Centro de Estudos Sociais da Universidade de Coimbra

\section{Edição impressa}

Data de publição: 1 Março 2012

Paginação: 47-66

ISSN: 0254-1106

Refêrencia eletrónica

Júlia Garraio, "Hordas de violadores. A instrumentalização da violência sexual em discursos anticomunistas alemães da Guerra Fria », Revista Crítica de Ciências Sociais [Online], 96 | 2012, colocado online no dia 15 fevereiro 2013, criado a 20 abril 2019. URL : http://journals.openedition.org/ rccs/4811; DOl : 10.4000/rccs.4811 


\section{jÚLIA GARRAIO}

\section{Hordas de violadores. A instrumentalização da violência sexual em discursos anticomunistas alemães da Guerra Fria*}

Nos discursos anticomunistas alemães da Guerra Fria, a imagem do Exército Vermelho como "horda de violadores" funcionou como estratégia de exclusão na construção de uma identidade nacional regida por "valores ocidentais". Analisarei a dimensão ideológica dos estereótipos de mulheres violadas e as construções de masculinidade que perpassam dois textos emblemáticos de memórias da fuga e expulsão dos alemães da Europa Central e de Leste e um romance de propaganda anticomunista norte-americano. Tentarei demonstrar que as violações de mulheres alemãs por soldados soviéticos no desfecho da Segunda Guerra Mundial foram interpretadas como produto de uma "barbárie asiática" e do comunismo. A instrumentalização dessas violações, ao diabolizar a União Soviética, favoreceu os dois pilares da política externa da República Federal da Alemanha: a integração europeia e a aliança transatlântica.

Palavras-chave: anticomunismo; era de Adenauer; Flucht und Vertreibung (fuga e expulsão); violência sexual; xenofobia.

A Alemanha pós-1945 é provavelmente um dos espaços onde as tensões e rivalidades ideológicas da Guerra Fria determinaram de maneira mais profunda a configuração dos estados e das identidades nacionais. A era de Adenauer (República Federal da Alemanha, 1949-1963) pode ser sintetizada como época conservadora e de progressiva integração em organizações políticas, económicas e militares do Ocidente. Sob a liderança do chanceler Konrad Adenauer (1876-1967), a República Federal da Alemanha esforçou-se por ganhar a confiança dos Aliados e assim obter um lugar entre as

\footnotetext{
* Investigação realizada no âmbito do projeto de pós-doutoramento financiado pela FCT "A memória do sofrimento: representações da violência na literatura alemã sobre a Segunda Guerra Mundial" (SFRH/BPD/28207/2006). O meu trabalho sobre a representação da violência sexual beneficiou muito da minha integração na rede "Sexual Violence in Armed Conflict" (SVAC) (http://www.warandgender.net/).
} 
nações ocidentais. A adesão à NATO em 1955, o rearmamento do país, bem como a emergência de um ideal de masculinidade fortemente associado a um militarismo supostamente não agressivo, devem ser entendidos dentro de um contexto de reinvenção da nação como parte do Ocidente. ${ }^{1}$ $\mathrm{O}$ anticomunismo foi central neste processo de formação da República Federal da Alemanha. Como nota Eric Weitz (2001: 220-2), a profunda desconfiança e o temor que Adenauer nutria pelo comunismo tê-lo-iam levado a defender enfaticamente a Aliança Transatlântica, assim dificultando a reunificação alemã no contexto da Guerra Fria. A posição do chanceler, que via conjugado na União Soviética tudo o que de pior pressentia na sua época - marxismo-leninismo, totalitarismo, pan-eslavismo, ateísmo... - era, aliás, em grande medida, consensual na esfera pública do jovem Estado, beneficiando da tradicional animosidade do SPD² para com os comunistas.

Esta política externa dominada por um desejo de aproximação ao Ocidente coexiste com uma forte pressão eleitoral interna com interesses a Leste. Refiro-me aos Vertriebene, os expulsos dos territórios perdidos pela Alemanha na guerra (Prússia Oriental, Silésia, Pomerânia) e de países vizinhos (Checoslováquia, estados do Báltico, etc.). ${ }^{3}$ Perfazendo cerca de $16 \%$ da população da República Federal, estes alemães organizaram-se em poderosas ligas e associações e afirmaram-se como grupo de pressão muito forte, determinante para as vitórias sucessivas dos conservadores. Este setor populacional, que teve até 1969 o seu próprio ministério, ${ }^{4}$ conseguiu ver contemplado no debate político uma das suas principais preocupações:

\footnotetext{
${ }^{1}$ Veja-se neste contexto alguma investigação de Robert Moeller. Nos seus trabalhos sobre o cinema popular alemão dos anos 50, o investigador analisa como o jovem Estado, depois do descalabro militar e da descredibilização da masculinidade "racialmente superior" promovida no Terceiro Reich, vai construir um ideal de masculinidade "moralmente superior": o cidadão respeitador da lei que não partilha obsessões nacionalistas e expansionistas, mas é capaz de, em caso de ameaça, pegar em armas para defender a família e o país (Moeller, 2001: 123ss.; Moeller, 2006b).

${ }^{2}$ Sozialdemokratische Partei Deutschlands [Partido Social-democrata da Alemanha].

${ }^{3} \mathrm{O}$ termo Vertriebene está intimamente ligado ao conceito Flucht und Vertreibung [fuga e expulsão], que se refere a uma das maiores migrações da história da humanidade (de finais de 1944 até 1949) e sobre a qual existe uma extensa bibliografia. A ofensiva soviética de 1945 provocou uma fuga maciça de alemães para Ocidente. Depois do fim da guerra várias regiões da Europa Central e de Leste são palco da expulsão violenta das comunidades alemãs. As decisões dos Aliados a favor da redefinição das fronteiras a Leste (com a Alemanha a perder uma parte significativa do seu território) e do princípio de privilegiar a homogeneidade étnica dos estados também contribuíram para a expulsão de milhões de alemães na segunda metade dos anos 40 . A experiência da fuga e da expulsão tornou-se um dos lugares de memória mais controversos da cultura alemã (veja-se, por exemplo, Hahn e Hahn, 2003).

${ }^{4}$ Bundesministerium für Vertriebene, Flüchtlinge und Kriegsgeschädigte [Ministério dos Expulsos, Refugiados e Vítimas da Guerra].
} 
a recuperação das suas casas, o que implicava a contestação das fronteiras saídas da guerra. ${ }^{5}$

Os governos de Adenauer conseguiram gerir de forma eficaz esta aparente contradição entre uma política externa virada para o Ocidente e uma base eleitoral interessada no Leste. Fomentaram-se condições que permitiram aos expulsos recomeçar as suas vidas na nova república e houve um esforço para os levar a ver o Estado como nova Heimat [pátria]: significativas ajudas estatais para promover o seu bem-estar económico, um discurso político sobre a República Federal como pátria de todos os alemães, favorecimento da integração da memória do Leste perdido na identidade nacional, boas relações do Estado com as ligas e apoio às suas iniciativas culturais. Os dirigentes políticos tinham certamente consciência de que o regresso era impossível: com a assinatura do Acordo de Potsdam de 2 de agosto de 1945, os Aliados ocidentais tinham sancionado a redefinição das fronteiras e a transferência de populações como forma de prevenir futuras tensões. As políticas de apoio do Estado aos expulsos podem ser vistas precisamente como meio de tornar essa perda menos dolorosa. A famosa visita de Adenauer a Moscovo em 1955 parece ser um sinal deste caminho traçado. O objetivo da histórica viagem não era a discussão das fronteiras nem o regresso dos expulsos, mas uma outra questão que apaixonava a opinião pública alemã: a libertação dos soldados alemães que ainda se encontravam em cativeiro soviético. O êxito da missão promoveu decisivamente o discurso oficial sobre a República Federal como pátria de todos os alemães.

O objetivo do presente texto é elucidar um aspeto desta aparente contradição entre uma política externa virada para o Ocidente e os interesses de uma base eleitoral interessada no Leste. Tentarei demonstrar através de discursos em torno das violações em massa de mulheres alemãs por soldados soviéticos, ${ }^{6}$ uma experiência central da fuga e expulsão, como a memória das vivências dos expulsos favoreceu os dois pilares da política externa da República Federal no contexto da Guerra Fria: a integração europeia e

\footnotetext{
5 Esta questão era então transversal aos principais partidos políticos, como atestam vários cartazes de campanha eleitoral da época, que exibem mapas da Alemanha nas fronteiras de 1937 e a legenda "Das ganze Deutschland soll es sein" [Tem de ser toda a Alemanha] (um cartaz da CDU de 1949 pode ser visto em http://www.wahlen-98.de/HTML/ARCHIV/AFSETTIMELINE. HTM; outro do SPD de 1948 pode ser visto em http://www.museen-sh.de/ml/digi_einzBild. php?pi=146_54-1996\&inst=146\&mab_id=146\&nameInst=Stadtmuseum\%20-\%20Warleberg er\%20Hof\&page $=7 \&$ action $=$ vonsuche $\& \mathrm{r}=82$ ). O SPD afastou-se destas reivindicações com a Ostpolitik de Willy Brandt. O Tratado de Unificação de 1990 pôs-lhes um ponto final.

${ }^{6}$ Entre os estudos sobre a violência sexual perpetuada pelo Exército Soviético contra as alemãs, contam-se Naimark (1995) e von Münch (2009).
} 
a aliança transatlântica. Utilizarei dois textos emblemáticos da expulsão para analisar como a imagem do violador soviético favoreceu, naquele contexto, a construção de uma certa identidade alemã europeísta e ocidental. A primeira obra, Martyrium und Heldentum Ostdeutscher Frauen. Ein Ausschnitt aus der Schlesischen Passion 1945/46 (1954) [Martírio e heroismo de mulheres da Alemanha Oriental: fragmentos do calvário silesiano 1945-46], é do teólogo Johannes Kaps, uma figura de grande relevo nos círculos católicos e na comunidade de expulsos radicada na Baviera, que se esforçou por sensibilizar o "Ocidente cristão" para a questão da expulsão dos alemães no desfecho da guerra. ${ }^{7} \mathrm{O}$ volume em análise é uma recolha de histórias de violência sexual, assassínios e privações que testemunham um confronto, a partir de uma perspetiva alemã católica, com as violações de alemãs. ${ }^{8}$ O segundo texto, Ostpreußisches Tagebuch. Aufzeichnungen eines Arztes aus den Jabren 1945-1947 [Diário prussiano. Anotações de um médico entre 1945 e 1947] (1961), ${ }^{9}$ é de Hans Graf von Lehndorff, descendente de uma influente família prussiana e personalidade de grande relevo entre os

\footnotetext{
7 Oriundo de família católica, Johannes Kaps (Breslau, 1906 - Munique, 1959) foi sagrado padre em 1935. Em 1939, pouco depois do rebentar da Segunda Guerra Mundial, regressa a Breslau. Segundo Hans-Ludwig Abmeier, Kaps ter-se-ia empenhado na libertação de padres perseguidos e teria tentado evitar a deportação de judeus e de "mestiços" (Abmeier acrescenta, porém, que, devido à destruição da guerra, a documentação comprovativa é escassa). Kaps viveu a capitulação de Breslau a 6 de Maio de 1945, testemunhando as atrocidades cometidas contra a população alemã. Em Agosto de 1945 deixa a cidade e refugia-se no Ocidente, onde relata a situação miserável da população alemã da Silésia. Viaja até Roma para informar o Papa Pio XII. Nos anos seguintes, empenhou-se em prestar apoio aos expulsos radicados na República Federal da Alemanha. Em 1952, passa a dirigir os Serviços de Registo Paroquial da Igreja Católica e Arquivo dos Expulsos (Katholischen Kirchenbuchamtes und Archivs für Heimatvertriebene) em Munique. A sua trilogia sobre a Silésia foi traduzida nos anos 50 para inglês, francês, italiano, espanhol e português com o intuito de internacionalizar o problema dos expulsos, no sentido dos objetivos traçados pelo então Ministro dos Expulsos Hans Lukaschek (Abmeier, 2000/2001: 183-185). A tradução portuguesa de Hans Fading, Martírio e heroísmo de mulheres da Alemanha Oriental: fragmentos da história trágica silesiana 1945-46, foi publicada em 1957, pela editora católica alemã responsável pelo original (Christ Unterwegs).

${ }^{8}$ A obra fecha uma trilogia sobre o fim da Silésia alemã. Antes já tinham sido publicados Vom Sterben schlesischer Priester 1945/6 [Sobre a morte de padres da Silésia] (1950) e Tragödie Schlesiens 1945/6 in Dokumenten [Tragédia da Silésia 1945/6 em documentos] (1952/53). Os relatos transcritos no volume de 1954 foram recolhidos maioritariamente em inícios dos anos 50 para a obra inédita do autor Beiträge zur Geschichte der Erzdiözese Breslau in den Schicksalsjabren 1945 bis 1951 [Contributos para a história da arquidiocese de Breslau nos anos fatídicos de 1945 a 1951].

${ }^{9}$ O diário foi publicado originalmente em 1960 no contexto do projeto governamental de recolha de informação sobre a expulsão Dokumentation der Vertreibung der Deutschen aus Ost-Mitteleuropa [Documentação da expulsão dos alemães da Europa de Leste e Central] com o título Ein Bericht aus Ost- und Westpreußen 1945-1947. Em 1961, foi editado como publicação autónoma (München: Biederstein) com o título pelo qual é atualmente conhecido, assistindo até ao presente a numerosas reedições. Nos anos 60 foi traduzido para várias línguas.
} 
círculos de expulsos..$^{10} \mathrm{O}$ seu diário, apadrinhado pelas instâncias oficiais da República Federal, é um dos textos de memórias da expulsão que gozou de maior êxito junto do público na época. Por fim, defenderei que a imagem do violador soviético que perpassa estes relatos dos expulsos acaba por desempenhar uma função semelhante à que encontramos num romance de propaganda norte-americano que teve enorme êxito na Alemanha dos anos 50: The Big Rape (1951), de James Wakefield Burke. ${ }^{11}$

A Ásia ou o Leste enquanto encarnação de um Outro bárbaro, perigoso, cruel e sem cultura é recorrente na construção de identidades europeias e ocidentais. A partir da Revolução de Outubro, a Rússia (e, posteriormente, a União Soviética) surge como catalisador de medos, como materialização do "monstro" do Leste, revestindo-se o anticomunismo gradualmente de tópicos orientalistas. O bolchevismo e o comunismo não são entendidos como fenómenos europeus e ocidentais, tornando-se antes marcas de um contramodelo vindo de fora. O espaço alemão é paradigmático desta significação da Rússia bolchevique como encarnação do Outro absoluto (ver, por exemplo, Ayçoberry, 2003; Moore, 2003). Estas fobias associadas ao anticomunismo, presentes em diversos países europeus, atravessam o século xx alemão e protagonizam algumas das continuidades mais óbvias

${ }^{10}$ Hans von Lehndorff (Graditz bei Torgau, 1910 - Bona, 1987), membro de uma antiga linhagem da nobreza prussiana, tem entre os seus familiares nomes importantes da história da Alemanha do século Xx: o avô, Elard von Oldenburg-Januschau (1855-1937), foi uma figura influente do campo conservador da República de Weimar e o primo Heinrich Graf von Lehndorff-Steinort era um dos conspiradores do 20 de julho, que foi executado em setembro de 1944. Hans von Lehndorff estudou Medicina e dirigia um hospital militar em Königsberg quando o Exército Vermelho conquistou a cidade. Fugiu para o Ocidente em 1947. Manteve-se ligado às associações de expulsos desde a chegada à futura RFA. Em 1981, recebeu o prémio mais conceituado das associações de expulsos da Prússia Oriental, o Preußenschild da Landmannschaft Ostpreußen (Hamburgo).

${ }^{11}$ Os textos que são objeto deste artigo inserem-se numa linha de instrumentalização ideológica da violência sexual contra as alemãs na Segunda Guerra Mundial. Embora a memória destas violações tenha tido forte ressonância em meios nacionalistas, anticomunistas e mesmo em discursos revisionistas, é importante não colar a temática por si só a essas tendências e não ignorar a profusão de textos de outros quadrantes que abordam o tema. Desde logo, existem alguns testemunhos russos, entre os quais se destacam Lew Kopelew (a autobiografia em que relata a violência do Exército Vermelho para com a população alemã foi publicada na República Federal da Alemanha em 1976 com o título Aufbewahren für alle Zeit e um posfácio do escritor Heinrich Böll) e Alexander Soljenítsin (as suas memórias das atrocidades cometidas contra os alemães na tomada da Prússia Oriental deram origem ao poema publicado em 1976 na República Federal da Alemanha Ostpreußische Nächte. Eine Dichtung in Versen). Do lado alemão existem vários relatos, diversas memórias e mesmo alguns textos literários que divergem do quadrante ideológico dos textos analisados neste artigo (por exemplo, o romance Westend, de Annemarie Weber, publicado em 1966, ou o relato Die Stunden der Frauen. Nach einer Erzählung von Libussa Fritz-Krockow, de Christian Graf von Krockow, publicado em 1988). Uma grande parte dos estudos sobre a presença da temática na cultura alemã tem por objeto o documentário sobre as violações em Berlim em 1945 da realizadora feminista Helke Sander, BeFreier und Befreite, filme que em 1992 foi acompanhado de grande êxito junto do público e de acesa polémica. 
entre o Terceiro Reich e a República Federal da Alemanha. Neste contexto, são recorrentes imagens terríveis de violência sexual, como atesta a propaganda antibolchevique nazi, que, sobretudo nos últimos meses da guerra, não cessava de amedrontar a população com as "hordas de violadores" soviéticos. ${ }^{12}$ Ora, como nota Atina Grossmann, precisamente neste ponto a propaganda não deixou de ter algo de premonitório, o que ajuda a perceber o impacto desses discursos e imaginários nacional-socialistas na memória alemã da derrota, bem como a perceção que os alemães criaram de si como povo de vítimas (1995: 113-117; 1998: 221-24).

A propaganda política conservadora da época de Adenauer serviu-se abertamente da experiência traumática das violações de mulheres alemãs por membros do Exército Vermelho para justificar posicionamentos políticos, promovendo imagens da União Soviética como uma masculinidade agressiva e repelente. ${ }^{13}$ Veja-se um cartaz de 1952 do Volksbund für Frieden und Freibeit [Liga popular para a paz e a liberdade] (organização criada em 1949) que alude às violações, usando-as como metáfora para a amizade germano-soviética, com o intuito de denunciar o Estado alemão rival como fruto da subjugação de uma Alemanha feminina por uma União Soviética masculina. Elisabeth Heineman presta especial atenção a um cartaz da coligação política conservadora CDU - "Nein, darum CDU" [Não, por isso CDU] - que retrata a União Soviética como homem asiático ameaçador. Conclui que este tipo de imagética, onde ecoa a milenar fobia das "hordas de violadores" de Gengis Khan, que tanto destaque tinha tido na propaganda da guerra, sinaliza como a violência sexual contra as alemãs funcionou na República Federal da Alemanha como expressão da barbárie asiática e metáfora para a brutalização da Alemanha e da sua cultura cristã ocidental pelo comunismo (Heineman, 1996: 355, 367-73). As violações não foram, assim, recordadas na esfera pública como experiências de violência sexual contra mulheres e adolescentes presentes em conflitos armados marcados por culturas patriarcais e com uma forte componente étnica. Em vez disso, transformaram-se em imagens políticas fortemente ancoradas nos discursos da Guerra Fria. Os dois textos alemães que aqui irei analisar, bem como o

\footnotetext{
${ }_{12}$ A fobia das "hordas de selvagens" da Mongólia, ansiosas por assassinar, pilhar, destruir e violar, fora um dos medos mais fomentados e explorados pelas autoridades nacional-socialistas para mobilizar a população na luta contra a ofensiva soviética, sobretudo após o massacre de Nemmersdorff (outubro de 1944), quando mulheres e adolescentes alemãs foram brutalmente violadas e assassinadas. Sobre o uso de estereótipos racistas na diabolização da União Soviética na Alemanha pré-1945 (não exclusivamente nos círculos nacional-socialistas) e na imagem do soldado violador da propaganda de guerra ver, por exemplo, Ayçoberry (2003: 455-65) e Moore (2003: 31-42).

${ }_{13}$ Poder-se-ão ver miniaturas de alguns destes cartazes em http://userpage.fu-berlin.de/roehrigw/ lva/ws9596/texte/kk/dhm/bsp.html, consultado a 08.03.2012.
} 
romance The Big Rape, testemunham exemplarmente esta significação da violência sexual.

\section{Mártires do bolchevismo}

No prefácio da obra de Kaps, da responsabilidade de Joseph Ferche, que se apresenta como o único bispo sobrevivente da Silésia que vivera como testemunha ocular a invasão do inimigo de Leste, as atrocidades que vitimaram a população alemã no desfecho da guerra são apresentadas como parte de uma história antiquíssima de sofrimento cristão às mãos dos infiéis: "Este livro deverá gravar para a História a heroicidade das mulheres e das raparigas alemãs durante o assalto das hordas bolcheviques e servir de advertência ao Ocidente cristão e ao mundo.” (Kaps, 1954: 7) ${ }^{14}$

A Silésia de 1945/46 surge assim, nas palavras do Bispo, como arena de mártires, como espaço de provação para os crentes (ibidem: 7). Por isso, a obra tem como mote uma citação do Breviário Romano referente à Virgem e Mártir Santa Lúcia: "Se me violentares contra a minha vontade, a minha castidade ser-me-á duplamente recompensada" (ibidem: 3). Maria Goretti, a jovem católica italiana de doze anos assassinada em 1902 numa tentativa de violação, e a cerimónia da sua canonização em 1950 desempenham um importantíssimo papel na introdução. Goretti é apresentada como antecessora das alemãs na guerra: "No Leste, tivemos centenas de Marias Goretti: quem fala delas?" (ibidem: 9). Os próprios testemunhos, recolhidos entre alemães crentes, em que se nota um elevado número de padres e freiras, são dominados por palavras e imagens do foro religioso. ${ }^{15} \mathrm{E}$ ao imaginário cristão que os expulsos vão buscar uma linguagem e categorias do mundo para apreender as vivências do fim da guerra e da ocupação soviética. São disso exemplo os seguintes excertos (o primeiro é de uma freira e o segundo de uma "jovem mãe de Breslau"):

Os russos perderam o pudor, eram hordas de mongóis, como depois soubemos, os piores, algumas caras claramente satânicas. Então começou um autêntico martírio [...] (ibidem: 75)

Deve ter sido assim entre os primeiros cristãos, uma comunidade alegre e verdadeira, nada de falso. (ibidem: 126)

\footnotetext{
${ }^{14} \mathrm{Na}$ realização do presente estudo consultei apenas o original alemão. As traduções das citações desta obra, bem como das outras referidas neste estudo, são da minha responsabilidade.

15 Este elevado número de testemunhos de religiosos, bem como a forte presença de imagens do foro cristão nas palavras dos expulsos, advém desde logo do método de recolha da documentação. Kaps conviveu sobretudo com expulsos radicados na zona de Munique que frequentavam a Igreja.
} 
A violência sexual permite diabolizar a União Soviética enquanto regime que rompe as normas sociais e morais mais básicas ao quebrar violentamente os pilares da sociedade patriarcal e da moral cristã: não respeita a virgindade feminina nem os laços do casamento; não frena a luxúria perante as esposas de Deus. Os abundantes casos de violação e assassínio de freiras, alguns relatados na primeira pessoa (por exemplo: Kaps, 1954: 43ss.), a par da profanação/violação de cadáveres (ibidem: 82), surgem como exemplo máximo da ausência de valores, do caos civilizacional e da selvajaria imputados pelos testemunhos aos vencedores. Veja-se, por exemplo, a violação e morte de uma freira cega e surda de 85 anos (ibidem: 90). O seguinte testemunho sintetiza a mensagem que percorre todo o volume de culpabilização do ateísmo e do comunismo pela violência sexual:

Esta é a grande tragédia do povo russo: com a religião retirada ao povo violentamente, este povo não conhecia o sétimo nem o décimo mandamento, nem tão pouco o sexto e o nono! Muitas mulheres e raparigas foram desonradas de forma violenta e totalmente animalesca. (Kaps, 1954: 99)

É a renúncia a Deus após a Revolução de Outubro que é tida como responsável pelos atos de violência. Neste contexto de culpabilização do comunismo são de extrema importância as últimas páginas dedicadas aos "bons eslavos", os polacos e os russos que protegeram mulheres alemãs. Já na introdução ao segundo capítulo, Kaps defendera a necessidade de distinguir uma minoria de polacos comunistas, que, dominados pelo ódio e sob a influência dos soviéticos, participaram nas violações, da maioria da população polaca, que seria boa e crente.

Os silenciamentos e as omissões do texto apontam desde logo para o carácter problemático da significação da violência sexual como marca do comunismo. Não são referidos os elevadíssimos níveis de violência sexual perpetrada pelas tropas alemãs no Leste ${ }^{16}$ nem as violações de alemãs por membros das forças aliadas ocidentais. ${ }^{17}$ Tal prende-se em parte com a visão binária e maniqueísta do fenómeno: sendo a violência sexual uma marca dos não crentes, não é concebível, na lógica do texto, que nações cristãs a pratiquem em larga escala. Uma vez que os abusos sofridos pelos alemães da Silésia não são analisados no contexto da espiral de violências da guerra e dos crimes alemães no quadro político do ataque à União Soviética,

\footnotetext{
${ }^{16}$ Sobre a violência sexual no ataque à União Soviética, veja-se, por exemplo, Mühlhäuser (2010).

${ }^{17}$ Sobre a violência sexual perpetrada por membros do exército norte-americano, veja-se, por exemplo, Lilly (2007).
} 
as alemãs violadas surgem como vítimas de um conflito que ultrapassa o caso concreto da Segunda Guerra Mundial. As histórias narradas são sobre cristãs abusadas por bolcheviques, com a violência a ser integrada, por um lado, numa narrativa de perseguição aos cristãos e, por outro, na profícua tradição das mártires cristãs da castidade (Goretti, Santa Lúcia e outras), o que faz da União Soviética sobretudo um carrasco dos crentes. As violações aparecem como repetição de um fenómeno a-histórico: a luta do Mal contra o Bem, do pecado contra a castidade, da barbárie contra a civilização. Em termos geográficos e culturais, as fronteiras são fáceis de traçar: do Leste bolchevique (Ásia) vem a barbárie, no Ocidente cristão (Europa) vive o Bem. É aí, a essa Europa cristã, que pertenceria o povo alemão.

Os objetivos de Martírio e heroísmo de mulheres da Alemanha Oriental no quadro da geopolítica da Guerra Fria e do anticomunismo são indissociáveis de um subtexto que apela à recristianização da Europa e que pode ser sintetizado pelas palavras finais de um testemunho: "Deus todo-poderoso e bondoso, dai aos russos a graça da conversão e oferecei a paz a todos os povos" (Kaps, 1954: 46). As referências aos "bons eslavos" devem também ser analisadas neste contexto. Segundo Kaps, as experiências terríveis da guerra tinham aproximado muitos, dos dois lados, do divino e seria este regresso a Deus a força que poderia possibilitar a reconciliação entre os povos e um futuro de paz: "Assim tenhamos a esperança de que as vítimas inocentes do Leste alemão não tenham sofrido em vão, mas que tenham aberto os alicerces para um futuro cristão melhor para o povo alemão e os povos eslavos" (ibidem: 23). Esta vontade de recristianizar a Europa visa também práticas sociais da República Federal da Alemanha. Na introdução, o bispo Ferche afirma que os sacrifícios relatados deveriam servir de exemplo numa época em que tantas alemãs arriscavam levianamente a honra (ibidem: 8). Ao longo do volume torna-se óbvio que a recristianização é entendida no texto como regulamentação do comportamento moral e das normas sexuais (desaprovação do sexo fora do casamento, condenação do aborto, promoção de um ideal de mulher como esposa e mãe), o que coloca a obra nitidamente dentro da ofensiva conservadora da época em relação aos hábitos sociais. ${ }^{18}$

\footnotetext{
${ }_{18}$ Analiso a maneira como Kaps usa a violência sexual na guerra para promover pontos centrais da doutrina católica da época em "Mártires cristãs do bolchevismo: as violações de alemãs na Segunda Guerra Mundial sob um olhar católico", in Mário Matos e Orlando Grossegesse (orgs.), Intercultural Mnemo-Graphies / Mnemo-Grafias Interculturais / Interkulturelle Mnemo-Graphien. V. N. Famalicão: Edições Húmus (no prelo).
} 


\section{Uma avalanche asiática}

O diário de Lehndorff também recorre ao imaginário bíblico para representar os alemães como perseguidos, associando-os ao povo eleito e aos seguidores de Cristo, enquanto os soviéticos surgem como os seus implacáveis carrascos. ${ }^{19}$ Tal como no volume de Kaps, os sofrimentos das alemãs são imbuídos de referências cristãs. A Doutora é emblemática desta tendência para representar as vítimas de violação como figuras inocentes, sacrificadas pela bestialidade e luxúria dos invasores. É de extrema importância a aproximação estabelecida entre a figura e dois importantes textos bíblicos, a Epístola aos Hebreus e sobretudo o oitavo capítulo da Epístola aos Romanos (é entre estas páginas que o narrador descobre o diário da companheira após a sua morte). Este texto bíblico, destinado a oferecer orientação espiritual aos primeiros cristãos numa época de perseguição, baseia a redenção do pecado carnal numa superação da carne através do espírito. O corpo pode ser maltratado e destruído, mas, se o espírito permanecer puro, a alma não precisará de temer a morte nem a condenação eterna. ${ }^{20}$ Esta questão é determinante para a imagem que o texto constrói da vítima: a carne, o aspeto físico material, fora conspurcado, mas o espírito, norteado pela dedicação ao próximo e pela fé cristã, mantivera a pureza.

Ainda que Lehndorff preste mais atenção aos crimes do Terceiro Reich (embora tendencialmente dentro de uma narrativa dos alemães como vítimas de Hitler), ${ }^{21}$ o relato dos anos que passou sob ocupação soviética perpetua as dicotomias centrais de Kaps: civilização/barbárie, cristianismo/ /comunismo. O Leste é desde o início associado à selvajaria. As manadas esfomeadas daí provenientes (indício do avanço soviético) são vistas como anúncio do caos (Lehndorff, 2005: 10). As fogueiras no pátio do hospital, à volta das quais os vencedores apreciam os objetos pilhados, lembram ao narrador um acampamento cigano e dão-lhe a sensação de estar na Ásia profunda; descreve então Königsberg como uma ilha invadida por uma

\footnotetext{
${ }^{19}$ Eis alguns exemplos: as pragas do Antigo Egito são invocadas para descrever os sofrimentos dos alemães às mãos dos soldados embriagados (Lehndorff, 2005: 72); o narrador vê-se na pele de Moisés quando sente a tentação de matar um soldado soviético (ibidem: 75); ao ser preso, pensa em Jonas engolido pela baleia (ibidem: 80); durante uma tempestade, imagina-se na situação de Noé (ibidem: 140); quando foge de Königsberg, recebe das amigas uma reprodução de Rafael da libertação de São Pedro (ibidem: 163).

${ }^{20}$ Kaps desenvolve um raciocínio próximo ao invocar palavras de Santo Agostinho e uma epístola de 1945 do bispo húngaro Josef Mindszenty para absolver do pecado as mulheres violadas pelos soviéticos. ${ }^{21}$ É de grande importância o esforço de Lehndorff de apresentar a sua família como exemplo de sofrimento alemão às mãos das autoridades nazis e dos soviéticos: por exemplo, a mãe, que passara pelas prisões da Gestapo, foi morta pelos soviéticos em Janeiro de 1945, a tia foi presa pelas autoridades nazis e sofreu posteriormente os tormentos da ocupação soviética, o primo Heinrich Graf von Lehndorff-Steinort foi executado em 1944 por participação no atentado contra Hitler.
} 
lava cinzenta (ibidem: 68, 70). Os vencedores aparecem como encarnação de uma barbárie oriental, que destrói pessoas, civilização e natureza. A chegada do Exército Vermelho traduz-se na destruição violenta da cultura alemã, no desmoronamento de uma ordem cristã e na instauração do caos. Os soldados, sobretudo no contexto das violações, são referidos por termos que exprimem a brutalidade animal: "hienas" (ibidem: 73), "babuínos" (ibidem: 77). Os soviéticos e seus colaboradores pilham, destroem, violam, dançam como selvagens e embebedam-se. Os alemães, em contrapartida, trabalham, limpam, cultivam a terra, entreajudam-se, tentam consolar os que mais sofrem, leem a Bíblia, cantam e oram ao Senhor. ${ }^{22} \mathrm{~A}$ crença em Deus surge como ponto fulcral que diferencia os dois povos, tal como é sugerido quando o autor tenta explicar as violações:

E esta língua desafinada e de latidos, da qual a Palavra parece ter-se retirado há muito. E estas crianças encarniçadas, de quinze, dezasseis anos, que se atiram sobre as mulheres como lobos, sem realmente saberem o que está em causa. Isto nada tem a ver com a Rússia, nada tem a ver com um determinado povo ou raça - isto é o ser humano sem Deus. (Lehndorff, 2005: 67)

A suposta falta de cultura do povo russo é repetidamente insinuada no relato, mas é sobretudo o afastamento de Deus com a Revolução de Outubro que o texto responsabiliza pela violência sexual. O sofrimento alemão surge assim como produto de uma sociedade sem valores espirituais, numa leitura do passado de acordo com os discursos dominantes nas ligas e associações de expulsos da República Federal da Alemanha. ${ }^{23} \mathrm{O}$ diário, para além de perpetuar a imagem de uma Prússia Oriental de extrema beleza destruída pela fúria soviética, uma visão muito cara aos círculos dos expulsos, apresenta os alemães do Leste, tal como Kaps o faz, como vítimas sem responsabilidade pelos crimes cometidos pela Alemanha nacional-socialista, estilizando-os como paradigma de uma cultura ocidental cristã, um polo civilizador materializado numa sociedade ordenada e culta, ameaçada pelo Oriente. Kaps e Lehndorff revelam assim de forma exemplar como a experiência traumática da fuga e expulsão adquiriu uma dimensão religiosa e se predispôs para o combate anticomunista. Ao serem representados como expoentes de uma cultura cristã perseguida, os expulsos, bem como as mulheres violadas,

\footnotetext{
${ }^{22}$ Há momentos em que esta imagem é relativizada. Por exemplo, quando, a propósito do canibalismo entre alemães, Lehndorff reconhece que tais atos são causados pela fome (e não pela cultura asiática, como antes se dizia a propósito do canibalismo entre os russos) (2005: 160).

23 Sobre a memória do passado dominante nas ligas, ver, por exemplo, Hahn e Hahn (2003: 338-51), Moeller (2001: 51-87) e Münz e Ohliger (2003: 380-1).
} 
dissociavam-se do regime nacional-socialista, surgindo unicamente como mensageiros do terror soviético. ${ }^{24}$

A imagem homogénea e aterrorizadora do Exército Vermelho que perpassa os relatos dos expulsos favoreceu assim a descredibilização da República Democrática Alemã e a legitimação da República Federal da Alemanha e das potências ocidentais. Após a derrota militar absoluta da Alemanha em 1945 e no contexto das rivalidades internacionais, dos temores e do confronto ideológico da Guerra Fria, as histórias de perseguição e maus tratos pelo Exército Vermelho e as descrições de miséria e caos económico sob a ocupação soviética eram entendidas, em primeiro lugar, como provas do carácter pernicioso do comunismo e da sua incapacidade de proporcionar bem-estar aos povos. Para além disso, foram interpretadas como sinais da necessidade de uma rápida integração nas instituições políticas e militares ocidentais que se afirmavam como contrapoderes ao poder soviético e como sistemas económicos alternativos ao modelo comunista. Daí que a estrutura geográfica dos relatos seja tão importante: a sobrevivência apenas se torna possível com a promessa de chegada às zonas sob ocupação dos Aliados ocidentais. As paisagens idílicas do Leste poderiam estar perdidas, mas sob proteção do Ocidente era possível recomeçar uma vida com dignidade e guardar a memória do passado. Veja-se o final do diário de Lehndorff:

Agora chegou a hora de dar os primeiros passos no caminho que me oferece uma nova existência. E fui confrontado com a questão: como será essa nova existência e quem decidirá sobre ela? Será uma existência de indiferença, uma existência que nem precisa de ser vivida? Ou Deus, na sua misericórdia, permitirá que nos seja concedida, a mim e a todos os que viveram o mesmo, a graça de ao longo das nossas vidas podermos dizer algo sobre o que vimos e ouvimos? (2005: 286-7)

Desta maneira, este tipo de memórias favoreceu a construção (ou provavelmente a continuação) de um Outro absoluto, de um inimigo que, embora pudesse ser localizado em termos geográficos, era sobretudo o produto de construções culturais. Este inimigo asiático, brutal e ateu que emergia nos relatos dos expulsos ajudou a República Federal da Alemanha a definir-se na ordem internacional marcada pela Guerra Fria como parte da Europa Ocidental. Se o perigo estava a leste, então era a ocidente que se encontrava a salvação: na República Federal como Alemanha legítima

\footnotetext{
${ }^{24}$ Vários estudos mostram como a Guerra Fria favoreceu, na República Federal, a apropriação da fuga e expulsão como experiência coletiva alemã e apontam para a centralidade deste lugar de memória na construção de uma identidade nacional como povo de vítimas (e.g. Heineman, 1996; Moeller, 2001; Moeller, 2006a; Münz e Ohliger, 2003: 384-5; Schmitz, 2007).
} 
e com os Aliados Ocidentais e as suas estruturas políticas, militares e económicas (NATO e CE). Eram estas que poderiam proteger o Ocidente cristão de um Leste sem Deus.

\section{A Alemanha como corpo feminino a conquistar}

Ao instrumentalizar as violações para denegrir a União Soviética, os relatos dos expulsos aqui analisados convergem com um best-seller dos anos 50 que, à primeira vista, se encontra nos antípodas do discurso conservador cristão de Kaps e de Lehndorff. Refiro-me ao romance The Big Rape ${ }^{25}$ de James Wakefield Burke, um correspondente de guerra norte-americano que teria sido conselheiro de relações públicas do próprio General Clay ${ }^{26}$ em 1947-48. Apresentando-se como romance documental, o texto, que deverá ser lido antes de tudo como pulp fiction, ${ }^{27}$ parte de eventos históricos (as violações cometidas pelos soviéticos na conquista de Berlim) para criar uma teia ficcional de aventura e vingança recheada de encontros sexuais violentos e de sadismo. Martin Meyer suspeita que o romance tenha sido patrocinado pelas autoridades norte-americanas na luta contra a influência e expansão ideológica da União Soviética em solo alemão (Meyer, 2001: 168). ${ }^{28}$ The Big Rape tem efetivamente claros traços de propaganda anticomunista. Usando a sexualidade e estereótipos de masculinidade/feminilidade para criar construções e percursos nacionais, o texto pretende minar junto do público a credibilidade do poder soviético. Para tal, recupera estereótipos anteriores a 1945, como as hordas de mongóis. Veja-se a última aparição do Exército Vermelho no romance:

Oito ou dez soldados russos do tipo oriental estavam de pé ou às voltas à espera que o oficial se decidisse. O oficial era um tenente pequeno com uma cara redonda mongol e

${ }^{25}$ O texto original foi publicado em Franfurt am Main em 1951 pela editora Rudl. Em 1952 seguiu-se a edição em Nova Iorque pela editora Farrar, Straus and Young. Surgiram numerosas reedições, inclusivamente de outras editoras. Existem duas traduções alemãs: uma primeira da autoria de Werner Asendorf intitulada Die grosse Vergewaltigung (Frankfurt am Main: Rudl, 1952) e uma posterior de Ursula Lyn com o título Frau komm (Berlin: Amsel-Verlag, 1953, 1956).

${ }^{26}$ Lucius D. Clay (1897-1978) é conhecido pelo papel decisivo que desempenhou na Alemanha ocupada, sobretudo durante o bloqueio de Berlim (1948-49), um dos momentos mais tensos da Guerra Fria.

${ }^{27}$ Veja-se inclusivamente a qualidade do papel das várias edições e o material pictural da capa e da contracapa.

${ }^{28}$ As violações em massa tornaram-se de facto um problema grave de relações públicas para o poder soviético, o que explicaria, entre outros, a humilhante derrota do KPD (Partido Comunista Alemão) nas eleições de 1946 em Berlim no que era um antigo bastião comunista na República de Weimar. Por isso, algumas vozes ligadas ao SED (Sozialistische Einheitspartei Deutschlands, o partido que governaria a República Democrática Alemã) tentaram atribuir a persistência da memória das violações à propaganda ocidental (Grossmann, 1998: 223-225). 
olhos rasgados. Andava de cima para baixo enraivecido. Elas viram o Bruno atrás do grupo de soldados. Estava suspenso pelas mãos e pelos pés, as pernas abertas atadas entre duas árvores. Estava vivo mas praticamente inconsciente. Tinham-lhe arrancado a roupa e elas conseguiam ver as marcas de onde tinha sido esfolado e espancado. $O$ tenente vociferava, bramia. [...] O tenente fervia de raiva. [...] Apontou para o Bruno e gritou uma ordem: "Sderite s nego zhiviem kozhu!" [...]. A Lilo sabia que nunca iria dizer à Marlene o que estava a acontecer ao Bruno naquele momento. Sabia que nunca diria a ninguém que o tenente mongol tinha ordenado: "Esfolem-no vivo!" (Burke, 1953: 316-7)

As violações cometidas pelo Exército Vermelho são usadas para associar o comunismo à selvajaria e materializar a imagem de um Leste asiático, bárbaro e sanguinário. ${ }^{29} \mathrm{O}$ soldado soviético é repetidamente conotado com uma masculinidade ameaçadora, repelente e perversa: uso da violência para a gratificação sexual e a celebração da vitória militar, transmissão de doenças venéreas, embriaguez como estado normal para a sexualidade, partilha da mesma mulher em violentas orgias, presença de práticas alusivas à tortura nos encontros sexuais. Este tipo de masculinidade negativa contrasta radicalmente com a masculinidade saudável, protetora e mais potente, personificada pelos militares norte-americanos, ${ }^{30}$ que vemos chegar a Berlim no final do romance como salvadores:

Passados poucos dias, a Lilo estava no limite da mesma zona arborizada e observava o primeiro destacamento de americanos a entrar em Berlim. Viu o novo comandante para o setor americano de Berlim. [...] Atrás do carro do general vinha o seu número dois, um coronel [... . A Lilo sentiu-se despida quando [os olhos do coronel] se demoraram por um momento sobre ela. Havia algo de forte e feroz neste homem pequeno. [...] A Lilo recordou o que o Pavel lhe tinha dito sobre ele e agora, depois de o ver, percebeu porque é que os russos não queriam ter de lidar com ele.

Depois vinha a $82^{a}$ divisão de paraquedistas. Eram homens colossais - altos, enormes, poderosos. Parecia não haver soldados pequenos nem de estatura média entre eles.

\footnotetext{
${ }^{29}$ The Big Rape recupera estereótipos muito comuns no discurso antissoviético do Terceiro Reich, mas num contexto de rejeição do nacional-socialismo e sem enveredar pelo anti-semitismo da propaganda nazi (a identificação das chefias soviéticas com uma elite de judeus acusada de usar o inculto povo russo para destruir o Ocidente).

${ }^{30}$ Será desnecessário recordar que, na realidade, o exército norte-americano também teve de lidar com numerosos casos de violência sexual perpetrada pelos seus soldados contra mulheres e adolescestes alemãs (ver por exemplo Lilly, 2007). Atina Grossmann (1998: 225-6) recorre ao testemunho de alguns oficiais norte-americanos para concluir que, nos primeiros anos da ocupação, entre os norte-americanos se estava longe de mostrar surpresa ou desaprovação perante a violência sexual dos soviéticos para com as alemãs.
} 
Eram todos gigantes! Em contraste com os russos, havia algo de imediatamente penetrante e dominador nestas tropas. Tinham os uniformes bem arranjados, limpos e esmerados. Com as calças enfiadas nas botas de paraquedistas pareciam todos ter pernas extraordinariamente longas. As caras eram uniformemente claras e limpas. Todos pareciam estar contentes. Não havia rostos sombrios a cismar. (Burke, 1953: 317-8)

É esta masculinidade superior (tanto do ponto de vista moral como da própria potência física) que a protagonista aceita e para a qual se dirige no final do romance. Petra Goedde (1999) defende que os contactos pessoais de militares norte-americanos com mulheres alemãs ajudaram a transformar a perceção que os Estados Unidos tinham da Alemanha: de um agressor masculino a uma vítima feminina. The Big Rape exemplifica paradigmaticamente esta imagem feminizada do antigo inimigo como entidade frágil ameaçada por masculinidades perversas e perigosos. Com Lilo, é evidente a identificação entre corpo feminino e nação em busca de um rumo. Enquanto personificação da Alemanha vencida, a personagem funciona como uma espécie de batalha para o combate ideológico da Guerra Fria. Inicia a vida sexual com Bruno, o amigo de infância que se deixara manipular pelo regime, e que, como membro das SS, representa a Alemanha criminosa culpada de crimes de guerra nos campos de concentração. O fanatismo do jovem é decisivo para Lilo se desinteressar da relação precisamente no momento em que a derrota alemã se traduz na perda de poder desta masculinidade. Perante o perigo de violação, opta por se entregar a um dos conquistadores, Pavel, o atraente torcionário dos serviços secretos soviéticos. A protagonista experimenta então momentos de sedução e êxtase sadomasoquista com um vencedor da batalha de Berlim, mas o lado sombrio, calculista e mesmo cobarde do amante ${ }^{31}$ torna-se cada vez mais evidente e leva-a a perder o interesse. Por fim, vislumbra nos norte-americanos uma masculinidade protetora e os promotores de um futuro digno para si, a sua família e a Alemanha. Os parágrafos finais do texto - consciência por parte da protagonista da dimensão absoluta da derrota da Alemanha e decisão de se juntar aos antigos inimigos - revela um claro cruzamento da sexualidade com a política, ou antes, como a adesão da Alemanha aos Estados Unidos é metaforizada como entrega sexual feminina:

De repente, o coração dela foi atingido de maneira dura e profunda e incisiva pela consciência de que a Alemanha tinha perdido a guerra, estava totalmente derrubada,

\footnotetext{
${ }_{31}$ Lilo percebe que Pavel nunca iria ajudá-la a vingar-se dos dois soldados do Exército Vermelho que tinham violado a mãe e a irmã, pois temia a máquina repressiva soviética e prezava acima de tudo o seu poder como oficial soviético.
} 
literalmente caída de costas, abissalmente prostrada e finalmente kaputt! [...] A soluçar, como se o coração se tivesse estilhaçado em mil pedaços, atirou-se para o chão e chorou na terra. [...]

Levantou-se finalmente [...] Sentiu uma abertura no coração, uma frescura. Sorriu o seu sorriso enviesado. [...] Havia uma vingança fria em algo que tinha sido martelado repetidas vezes na sua cabeça. O Doutor Goebbels tinha-o pregado quase continuamente nos últimos dias da guerra. O Paul, o papá, o Bruno e o Pavel tinham dito: O Ocidente iria acabar por combater o Leste.

Quando o Ocidente e o Leste entrassem finalmente em guerra aberta, onde ficaria a Alemanha? Uma coisa era certa: a Alemanha seria o principal campo de batalha. O povo dela seria então novamente moído pelos motores da destruição. [...] Sobrevivência! Acima de tudo tinha de sobreviver. Se um número suficiente de alemães valentes conseguisse sobreviver, o Vaterland ${ }^{32}$ viveria. Ela tinha sobrevivido à violação de Berlim. De certeza que iria conseguir arranjar-se a partir daqui. O papá tinha-lhe feito um pequeno esboço dos americanos. O que viu agradou-lhe. Com o Bruno aprendeu quando se entregar; com o Pavel quando não se entregar. O que poderiam ensinar-lhe os americanos? Bem, estava pronta para encontrar o inimigo. [...] Caminhou com o passo confiante de quem vai para um dever agradável certo, e com a liberdade ágil de uma mulher que tinha caminhado habitualmente na sua infância, descalça e de pernas descobertas na areia do mar. Então seguiu caminho pela Argentinische Allee, em direção à bandeira americana, que ondulava na tarde de julho sobre o US Press Center. (Burke, 1953: 318-20)

Para a decisão final da protagonista são decisivos os conselhos do pai, que a alerta para a necessidade de se submeter à autoridade norte-americana, de aceitar a expiação da culpa, mas que também a consola com a vinda de um futuro de abundância sob a proteção dos Estados Unidos. Esta personagem, apresentada no romance como uma espécie de velha Alemanha conservadora que teria coexistido com o nazismo, a ele se tendo sujeitado sem partilhar os seus valores, é essencial para a redenção do povo alemão. Este aspeto contribuiu certamente para a adesão do público da República Federal da Alemanha ao texto. $\mathrm{O}$ romance oferece uma visão do passado em que a maioria dos alemães da década de 50 gostava de se rever e que no essencial não difere do que é postulado nas memórias de Lehndorff: os crimes cometidos durante o Terceiro Reich eram da responsabilidade de uma minoria (os dirigentes do Partido, as SS, a Gestapo); os alemães "comuns" eram

$\overline{32}$ No original encontra-se a palavra alemã Vaterland [pátria]. 
indivíduos moralmente dignos; a invasão soviética fora acompanhada por formas extremas de brutalidade que tinham injustamente atingido sobretudo a maioria inocente da população; mesmo para as vítimas do nazismo o poder soviético apenas acarretara mais sofrimento e morte. Neste último ponto, é de vital significado o destino das duas irmãs judias do romance: depois de terem conseguido sobreviver às perseguições anti-semitas do Terceiro Reich, são brutalmente violadas por um grupo de soldados bêbados do Exército Vermelho na noite anterior ao grande feriado soviético, o 1 de maio, vindo posteriormente a mais nova, de 12 anos, a falecer em consequência de uma doença venérea contraída nesse momento.

Este tipo de construção do passado baseada na diabolização do poder soviético e na vitimização da população alemã às mãos do Exército Vermelho não tinha como único alvo o público alemão. Ao mesmo tempo que tenta combater a influência cultural soviética e seduzir a população alemã com as vantagens de uma aliança forte com os Estados Unidos, o romance procura justificar perante o público norte-americano as novas alianças do seu país no mundo da Guerra Fria: os antigos aliados soviéticos eram agora os inimigos e os antigos inimigos alemães tinham passado a aliados.

\section{Considerações finais}

A constante objetivação do corpo feminino sensual, a repetida associação entre desejo, prazer sexual, perigo, poder e violência, um certo voyeurismo na descrição exaustiva dos corpos femininos violentados sexualizados, as abundantes descrições de encontros sexuais e a própria localização de um momento central da vingança da heroína num bordel de luxo (espaço inspirado provavelmente no famoso Salon Kitty de Berlim) são traços característicos de um tipo de literatura de entretenimento "para adultos", do esbater de fronteiras entre violência e libertinismo típico de uma certa pulp fiction em que se integra The Big Rape. Estes traços contrastam abertamente com a abordagem puritana e extremamente lacónica em questões sexuais que encontramos em Kaps e Lehndorff. Enquanto nestes últimos as vítimas de violação são seres assexuados e modelos de virtudes domésticas e cristãs, com Burke encontramos mulheres sexualizadas e disponíveis, corpos femininos para serem tomados e usufruídos e aptos também a serem usufruidores. No contexto ideológico da Guerra Fria, os dois estereótipos de mulher violada que subjazem aos textos - a mulher anjo e a mulher fatal - cumprem, porém, uma função idêntica relativamente à reinvenção política da Alemanha: testemunhar a brutalidade soviética e indicar que o caminho para a nova Alemanha, a boa Alemanha, estava com os Aliados ocidentais. 
Quando o tema das violações ganhou grande projeção mediática na Alemanha unificada, sobretudo no contexto da receção do documentário BeFreier und Befreite (1992), os textos aqui analisados já tinham caído em grande parte no esquecimento. $\mathrm{Na}$ altura falou-se constantemente da existência de um tabu em torno da violência sexual sofrida pelas alemãs. Como se depreende deste texto, as memórias das violações não eram uma temática nova no espaço público alemão; tinham, pelo contrário, um passado de instrumentalização ideológica, que não era imune a discursos racistas. O que a realizadora Helke Sanders e outras feministas alemãs que se interessaram pelo tema tentaram fazer não pode ser assim entendido como quebra de um tabu, mas antes como tentativa de resgatar a memória da violência sexual através da reinvenção de um discurso capaz de expressar esse sofrimento fora de moldes nacionalistas e xenófobos. Compreender os significados que a temática adquiriu na Alemanha pós-unificação exige assim ter em conta os discursos hegemónicos da era de Adenauer em que essas memórias tinham sido recordadas.

\section{Referências bibliográficas}

Abmeier, Hans-Ludwig (2000/2001), "Kardinal Bertrams Domvikare”, Oberschlesisches Jabrbuch, 16/17, 151-191.

Ayçoberry, Pierre (2003), „Der Bolschewik“, in Etienne François e Hagen Schulze (orgs.), Deutsche Erinnerungsorte I. München: Beck, 454-68.

Burke, James Wakefield (1953), The Big Rape. New York: Popular Library.

Goedde, Petra (1999), "From Villains to Victims: Fraternization and feminization of Germany, 1945-47”, Diplomatic History, 23(1), 1-20.

Grossmann, Atina (1995), „Eine Frage des Schweigens? Die Vergewaltigung deutscher Frauen durch Besatzungssoldaten", Sozialwissenschaftliche Informationen, 24, 109-119

Grossmann, Atina (1998), "Trauma, Memory and Motherhood. German and Jewish Displaced Persons in Post-Nazi Germany, 1945-1949”, Archiv für Sozialgeschicbte, 38, 215-239.

Hahn, Eva; Hahn, Hans (2003), „Flucht und Vertreibung“, in Etienne François e Hagen Schulze (orgs.), Deutsche Erinnerungsorte I. München: Beck, 335-351.

Heineman, Elisabeth (1996), "The Hour of the Woman. Memories of Germany's 'Crisis Years' and West German National Identity", The American Historical Review, 101(2), 354-395.

Kaps, Johannes (1954), Martyrium und Heldentum Ostdeutscher Frauen. Ein Ausschnitt aus der Schlesischen Passion 1945/46. München: Christ Unterwegs.

Lehndorff, Hans Graf von (2005), Ostpreußisches Tagebuch. Aufzeichnungen eines Arztes aus den Jahren 1945-1947. München: DTV. 
Lilly, Robert (2007), Taken by Force. Rape and American GIs in Europe during World War II. New York: Palgrave Macmillan.

Meyer, Martin (2001), “American Literature in Cold War Germany”, Libraries \& Culture, 36(1), 162-71.

Moeller, Robert G. (2001), War Stories: The Search for a Usable Past in the Federal Republic of Germany. Berkeley/ Los Angeles/ London: University of California Press.

Moeller, Robert G. (2006a), "The Politics of the Past in the 1950s: Rhetorics of Victimization in East and West Germany", in Bill Niven (org.), Germans as Victims. Remembering the Past in Contemporary Germany. Houndmills: Palgrave Macmillan: 26-42.

Moeller, Robert G. (2006b), "Victims in Uniform: West German Combat Movies from the 1950s", in Bill Niven (org.), Germans as Victims. Remembering the Past in Contemporary Germany. Houndmills: Palgrave Macmillan, 43-61.

Moore, Gregory (2003), "From Buddhism to Bolshevism: Some Orientalist Themes in German Thought”, German Life and Letters, 56(1), 20-42.

Mühlhäuser, Regina (2010), Eroberungen. Sexuelle Gewalttaten und intime Beziebungen deutscher Soldaten in der Sowjetunion 1941-1945. Hamburg: Hamburger Edition.

von Münch, Ingo (2009) „Frau, komm!“. Die Massenvergewaltigungen deutscher Frauen und Mädchen 1944/45. Graz: Ares.

Münz, Rainer; Ohliger, Rainer (2003), “Auslandsdeutsche”, in Etienne François e Hagen Schulze (orgs.), Deutsche Erinnerungsorte I. München: Beck, 370-388.

Naimark, Norman M. (1995), The Russians in Germany: A History of the Soviet Zone of Occupation, 1945-1949. Cambridge/ London: Harvard University Press.

Schmitz, Helmut (org.) (2007), A Nation of Victims? Representations of German Wartime Suffering from 1945 to the Present. Amsterdam: Rodopi.

Weitz, Eric D. (2001), "The Ever-Present Other. Communism in the Making of West Germany", in Hanna Schissler (org.), The Miracle Years: A Cultural History of West Germany 1949-1968. Princeton: Princeton University Press, 219-232. 
